\title{
Transformational leadership and employee organisational commitment in a rural-based higher education institution in South Africa
}

\begin{tabular}{|c|c|}
\hline \multicolumn{2}{|c|}{$\begin{array}{l}\text { Authors: } \\
\text { Wiseman Ndlovu }{ }^{1} \text { (D) } \\
\text { Hlanganipai Ngirande }^{1} \\
\text { Sam T. Setati } \\
\text { Simbarashe Zhuwao }^{1}\end{array}$} \\
\hline \multicolumn{2}{|c|}{$\begin{array}{l}\text { Affiliations: } \\
\text { 1Department of Human } \\
\text { Resource Management and } \\
\text { Labour Relations, University } \\
\text { of Venda, South Africa }\end{array}$} \\
\hline \multicolumn{2}{|c|}{$\begin{array}{l}\text { Corresponding author: } \\
\text { Wiseman Ndlovu, } \\
\text { wiseman.ndlovu@outlook.com }\end{array}$} \\
\hline \multicolumn{2}{|c|}{$\begin{array}{l}\text { Dates: } \\
\text { Received: } 31 \text { July } 2017 \\
\text { Accepted: } 28 \text { Mar. } 2018 \\
\text { Published: } 27 \text { June } 2018\end{array}$} \\
\hline \multicolumn{2}{|c|}{$\begin{array}{l}\text { How to cite this article: } \\
\text { Ndlovu, W., Ngirande, } \\
\text { H., Setati, S.T., \& Zhuwao, S. } \\
\text { (2018). Transformational } \\
\text { leadership and employee } \\
\text { organisational commitment in } \\
\text { a rural-based higher education } \\
\text { institution in South Africa. SA } \\
\text { Journal of Human Resource } \\
\text { Management/SA Tydskrif vir } \\
\text { Menslikehulpbronbestuur, } \\
\text { 16(0), a984. https://doi.org/ } \\
\text { 10.4102/sajhrm.v16i0.984 }\end{array}$} \\
\hline \multicolumn{2}{|c|}{$\begin{array}{l}\text { Copyright: } \\
\text { (C) 2018. The Authors } \\
\text { Licensee: AOSIS. This } \\
\text { is licensed under the } \\
\text { Creative Commons } \\
\text { Attribution License. }\end{array}$} \\
\hline \multicolumn{2}{|l|}{ Read online: } \\
\hline 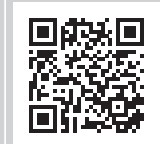 & $\begin{array}{l}\text { Scan this QR } \\
\text { code with your } \\
\text { smart phone or } \\
\text { mobile device } \\
\text { to read online. }\end{array}$ \\
\hline
\end{tabular}

Orientation: Transformation is a topical issue in South African higher education institutions. The slow and sluggish progress in attempts to transform the sector can be attributed to leadership and commitment of staff in these institutions.

Research purpose: The study investigated perceptions of employees and managers on the connection between transformational leadership style and employee organisational commitment in a selected rural-based higher education institution in South Africa.

Motivation for the study: This study was conducted to determine whether a perceived lack or the presence of transformational leadership style influences the level of organisational commitment of academic and non-academic staff members of a rural-based university. It is believed that in this way, the study may assist in determining and identifying the strategies to be used to improve the commitment of the staff members to attain the much needed transformation in higher education institutions.

Research design, approach and method: A self-administered questionnaire was used to gather data following a quantitative research design. The target population was divided into academic and non-academic strata. Pearson product moment correlation and multiple regression analysis were performed.

Main findings: The study found that transformational leadership style has a positive and significant relationship with affective commitment and moderate relationship with continuance commitment. On the contrary, it had no relationship with normative commitment. The study further revealed that perceived transformational leadership style explained the variance on employee organisational commitment. Therefore, the study concludes that effects of perceived transformational leadership style on employee commitment cannot be the same in different institutions and settings.

Practical and managerial implications: The study recommends that each institution should diagnose its situation for a better pictorial view of how transformational leadership affects employee organisational commitment in their organisation.

Contribution: The results of the study may assist leaders and employees in higher education institutions to enhance commitment for both academic and non-academic staff members through transformative leadership style to attain transformational goals of the South African higher education institutions as projected by the national government. Furthermore, this study will ensure the promotion and creation of transformative leaders who are adaptive and proactive in dealing with challenges of transformation in the former 'black' higher education institutions in South Africa and who also have staff members committed to this higher education transformation agenda.

\section{Introduction and background}

The modern trends of more dynamic and prompt change are cultivated by globalisation and adaptive human capital development and this has become the most important aspect of any organisation and government globally (Tremblay, Lalancette, \& Roseveare, 2012). Governments and organisations have invested extensively in human capital development as part of their strategic objective to address these hasty changes and to be ready to meet future human resource needs (Tremblay et al., 2012). However, in South Africa, equitable empowerment and accomplishment of higher education objectives cannot be possible without addressing the past injustices and imbalances in the education sector which among others excluded the black majority 
from acquiring a quality education (Nel et al., 2014; Tremblay et al., 2012). Since 1994, the South African government has put its attention to redressing these challenges brought by the exclusionary regime (Badat, 2010). Thus, the government formulated programmes for restructuring and transforming the education system (mainly former 'Bantu universities') based on the principles of equity, human rights, democracy and sustainable development (Ministry of Education, 2002).

\section{Employee organisational commitment}

To propel this strategic objective, committed employees are the key. Commitment to the organisation by employees or staff ensures that the company or institutions are more adaptive and productive. Various authors see employee organisational commitment as the relationship that exists between an individual and an organisation, attachment, identification with the organisation, the need to remain and the will to work hard to meet the organisational goals (Benligray \& Sonmez, 2012; Huey Yiing \& Bin Ahmad, 2009; Lo, Ramayah, Min, \& Songan, 2010). Ozsahin, Zehir, Acar, and Sudak (2013) have stated that employee organisational commitment is an employee's strong desire to remain a member of a certain organisation, his or her willingness to put up more effort on behalf of the organisation to achieve more, and acceptance of what the organisation stands for. Employee organisational commitment takes three faces: normative, continuance and affective commitment (AC). Meyer and Allen (1984) defined AC as a positive feeling of identification, attachment and involvement by an employee to the organisation or work with which he or she is involved. Continuance commitment is the extent to which the employee or an individual is willing to remain in the organisation as compared to the costs of leaving the organisation (Dhar, 2014). On the contrary, normative commitment refers to the obligation to remain with the organisation (Mignonac, Vandenberghe, Perrigot, El Akremi, \& Herrbach, 2015). Employee commitment is broadly affected by various factors, and among these factors, leadership is the key determinant to employee commitment to the organisation.

\section{Transformational leadership}

Transformational leadership is said to be a new paradigm, and leaders can use it to create an adaptive organisation (Bagraim, Cunnigham, Pieterse-Landman, Potgieter, \& Viedge, 2011). Bagraim et al. (2011) further state that a transformational leader is a futurist who creates a compelling vision that inspires total commitment to, and acceptance of, change by followers. Also, transformational leadership stimulates creativity, innovation and new ideas, which help the organisation to grow faster and adapt well to the dynamic environment (Avolio, 1999). Bushra, Usman, and Naveed (2011) further added that transformational leaders develop the vision, communicate it to employees and show consistency in the implementation of a vision, thereby generating or developing commitment from employees towards the organisation's vision. Roueche, Baker, and Robert (2014) further pointed out that perceived transformational leadership style ignites a positive change in employees' attitudes towards the strategies and goals of the organisation. Therefore, with the ever-changing environment, it will be important that organisations, including higher education institutions, adopt a flexible and adaptive leadership style to pursue transformation in these institutions. Thus, the mission of transforming higher education institutions in South Africa can be achieved through a shared vision between leadership and employees (Avolio, 1999; Ozsahin et al., 2013). Hence, the study adopted perceived transformational leadership style. Transformational leadership is a multifaceted concept, and it has four distinct but interrelated constructs. These are discussed below.

\section{Charisma or idealised influence}

This is the extent to which the leader acts in a pleasant way that stimulates employees or followers to develop an attachment with the leader. Idealised leaders exhibit views, believe in their followers and appeal to their employees (Van Knippenberg \& Sitkin, 2013). Thus, leaders set clear values and live up to them on a day-to-day basis and being a role model to their employees. Building genuine rapport between the leaders and the followers is the key to this kind of leadership style, and trust should be built on strong grounds of morality and ethics (Roueche et al., 2014; Van Knippenberg \& Sitkin, 2013).

\section{Inspirational motivation}

According to Balley (2007), the leader inspires and appeals to his followers through articulating the vision in a charismatic manner. Inspirational leaders challenge their employees by setting high standards, communicating about the future goals and giving the meaning to the job at hand (Ndunge, 2014). Inspirational motivation (IM) raises enthusiasm and optimism; intellectual stimulation (IS) inspires rationality and reasoning; individualised consideration (IC) focuses on the personal attention; and idealised influences give visions and drive to accomplish a set goal or mission (Dubinsky, Jolson, \& Spangler, 1995; Hackman \& Craig, 2013; Ndunge, 2014).

\section{Intellectual stimulation}

Intellectual stimulation refers to the extent to which the leader challenges perceptions, lobbies followers' ideology and takes risks (Northouse, 2015). These leaders arouse and encourage creativity from their subordinates. The main goal of this leadership feature is to provide a structure to the followers on how they connect to the leader, the company, objectives and one another (Northouse, 2010, 2015).

\section{Individualised consideration}

Individualised consideration refers to the extent to which the leaders attend to the individual needs of employees and guide employees in overcoming or dealing with these concerns (Northouse, 2015). The leader respects and shows appreciation of the contributions made by each member of the team in the organisation (Northouse, 
2010, 2015). This approach also gives leaders the opportunity to propel greater achievement and growth in the organisation.

\section{Transformational leadership and employee organisational commitment}

Studies have established varied links between transformational leadership behaviour and employees' organisational commitment (Ananthi \& Subramaniam, 2011; Bushra et al., 2011; Clinebell, Skudiene, Trijonyte, \& Reardon, 2013; Sušanj \& Jakopec, 2012). Earlier studies such as Shamir, Zakay, Breinin, and Popper (1998) revealed that transformational leaders have the ability to influence employees' organisational commitment by stimulating higher levels of intrinsic value associated with the attainment of goals and by emphasising the connection between employees' effort and goal achievement. Leaders of this type also generate a higher level of individual commitment on the part of the leader and followers to follow a common vision, mission and organisational objectives.

A study by Fasola, Adeyemi, and Olowe (2013) in the banking sector found that overall transformational leadership behaviour was positively and significantly related to employee organisational commitment $(r=0.507, p<0.01)$. Furthermore, the study established that perceived transformational leadership style facets had a positive and significant relationship with employee organisational commitment constructs: idealised influence and organisational commitment $(r=0.915$, $p<0.01)$, IM and organisational commitment $(r=0.793$, $p<0.01)$, IS and organisational commitment $(r=0.842, p<0.01)$, IC and organisational commitment $(r=0.901, p<0.01)$.

Similarly, an earlier study by Kent and Chelladurai (2001) found that IC has a positive correlation with both AC and normative commitment, however, with no relationship with continuance commitment. On the same study, Kent and Chelladurai (2001) found that there was a positive correlation between IS and both AC and normative commitment.

Correspondingly, Dunn, Dastoor, and Sims (2012) established that there was a relationship between transformational leadership behaviour and employee affective and normative organisational commitment. On the contrary, the same study by Dunn et al. (2012) revealed that there was no significant relationship between transformational leadership behaviour and employee continuance commitment. Literature has shown varied relationships between transformational leadership behaviour and employee organisational commitment with different environment and settings. Hence, the study was conducted in higher education institution based in rural areas.

\section{Problem statement}

Transformation of higher education institutions in South Africa remains a challenge, and in terms of overall output and equity of outcomes, graduate production remains very low (Cloete \& Maasen, 2015; Ministerial Oversight
Committee on Transformation, 2015; Higher Education, 2015). These challenges pose a great threat to both development and social cohesion in a small democracy like South Africa as it breeds high inequality rates (Soudien, 2013). Thus, less skilled people in the country feel left out by the rest of the world community who are perceived or seen as better off (Department of Higher Education and Training, 2015). In response to the ever-changing and growing lacuna between the poor and the rich, leaders need to spearhead transformation especially in rural-based higher education institutions, and this cannot be achieved by leaders alone without committed staff (Aydin, Sarier, \& Uysal, 2013). As studies have shown, that leadership style(s) chosen have great influence on the degree of employee organisational commitment of an organisation. Therefore, there is a need to explore the connection between perceived transformational leadership style and employee organisational commitment in a rural-based higher education institutions in South Africa.

\section{Research objectives}

The objectives of the study are as follows:

- To determine the relationship between perceived transformational leadership style and employee organisational commitment (affective, continuance and normative) in a rural-based higher education institution.

- To determine which of the perceived transformational leadership style constructs predicts the most employee organisational commitment (affective, continuance and normative) in a rural-based higher education institution.

\section{Study hypotheses}

H1: There is a relationship between the perceived transformational leadership style and affective commitment.

H2: There is a relationship between the perceived transformational leadership style and normative commitment.

H3: There is a relationship between the perceived transformational leadership style and continuance commitment

H4: Transformational leadership constructs predict the facets of employee organisational commitment

\section{Study methodology}

This study used a survey research technique following the quantitative approach. The University of Venda has $(N=800)$ staff members who are both academic and non-academic, and these formed the total target population. To determine the sample size from each stratum, the researcher used a Raosoft sample size calculator, which calculates sample based on 95\% confidence interval, 5\% margin of error and with the assumption of $50 \%$ response rate. Based on the Raosoft sample calculator, the recommended sample size for the University of Venda is 260. Thus, the total sample size was $(n=260)$ for this study. 


\section{Measuring instruments}

A Multifactor Leadership Questionnaire (MLQ) (Bass \& Avolio, 1993) revised by Avolio, Bass and Jung (1995) was used to measure perceived transformational leadership style. This is a 24-item questionnaire that measures transformational leadership and is scored on a 5-point Likert scale ranging from 1 (strongly disagree) to 5 (strongly agree). It has sub-scales under transformational leadership, which are charisma, IM, IS and IC. Acar (2012) found that this instrument has a reliability Cronbach's alpha coefficient of between 0.893 and 0.895 for transformational leadership subscales. The instrument has been used previously, and it has been proved applicable and valid (Acar, 2012; Covey, 2007; Munyeka \& Ngirande, 2014).

Employee Organisational Commitment Questionnaire (OCQ) (Allen \& Meyer, 1990) was used to assess employee organisational commitment. This is a 15 -item questionnaire that measures the three dimensions of employee organisational commitment (normative, affective and continuance commitment). It is scored on a 5-point Likert scale ranging from 1 (strongly disagree) to 5 (strongly agree). This questionnaire has a reliability of 0.977 using a strict test (Top, Oge, Atan, \& Gumus, 2015). This is a valid and reliable instrument, which has been used by various scholars in testing and checking employee organisational commitment (Munyeka \& Ngirande, 2014; Top et al., 2015).

\section{Data analysis}

The Statistical Package for Social Sciences Programme (SPSS) version 23 was used to analyse and draw meaning from the data collected (IBM-SPSS Institute, 2013). In this study, the Pearson's correlational analysis was used to check the relationship between the perceived transformational leadership style and employee organisational commitment (normative, affective and continuance). Regression analysis was further used to test if transformational leadership can predict different facets of employee organisational commitment (affective, continuance and normative).

\section{Factor analysis}

As a result of using the existing questionnaires that have been applied in many different situations and environments, factors to these variables are already known. Based on this, it is believed in this study that the systematic inter-dependence of the latent factors of commonality is known, and hence, factor analysis was not performed in this regard.

\section{Demographic profile of the respondents}

Table 1 shows the demographic variables of the study recipients. As shown, the majority of the respondents were males $93(52.2 \%)$, and females were $82(46.1 \%)$. Also, most of the respondents (64) were between the ages of 40 and 49 years $(64 ; 36.3 \%)$, followed by 50 and 59 years $(46 ; 25.8 \%)$ and the least being those in the age of 60 years and above $(10 ; 5.6 \%)$.

\section{Reliability analysis}

A reliability analysis was performed to determine the internal consistency of the items, using SPSS for reliability analysis, and all items that had total-correlation value below 0.30 were deleted. Pallant (2010) pointed out that Cronbach's alpha of $\alpha=0.70$ is the acceptable value. Results in Table 2 show that all the constructs were reliable as they surpassed the alpha coefficient of 0.70 . Continuance commitment had the highest alpha coefficient value $(\alpha=0.921)$, followed by IS $(\alpha=0.854)$. The reliability analysis paved the way for Pearson's correlation and regression analysis. The reliability scores were acceptable $(\alpha=0.70)$.

\section{Study results}

The results in Table 3 show that perceived transformational leadership style is positively and significantly related to AC $(r=0.521 *, p=0.004)$ and continuance commitment $(r=0.472 *, p=0.003)$, respectively. However, perceived transformational leadership style is not significantly related to normative commitment $(r=0.165, p=0.072)$.

The correlational analysis between AC and perceived transformational leadership style constructs in Table 3 shows that AC has a strong positive significant relationship with IS $\left(r=0.844^{*}, p=0.007\right)$ and a moderate positive relationship with IC ( $r=0.451 *, p=0.005)$. Moreover, AC has no significant relationship with idealised influence $(r=0.570, p=0.088)$ and

TABLE 1: Characteristics of the participants $(N=176)$.

\begin{tabular}{llcc}
\hline Item & Category & Frequencies & Percentage \\
\hline Gender & Female & 82 & 46.1 \\
& Male & 93 & 52.2 \\
& Missing & 1 & 0.6 \\
Age & 30 and below & 19 & 10.7 \\
& $31-39$ years & 31 & 17.4 \\
& 40-49 years & 64 & 36.3 \\
& 50-59 years & 46 & 25.8 \\
& 60 and above & 10 & 5.6 \\
& Missing & 7 & 3.9 \\
\hline
\end{tabular}

TABLE 2: Reliability of the perceived transformational leadership style and employee organisational commitment constructs.

\begin{tabular}{llcc}
\hline Scale & Cronbach's alpha $(\boldsymbol{r})$ items & & Interpretation \\
\cline { 3 - 4 } & & Cronbach's Alpha scores & Number of items \\
\hline Transformational leadership & Idealised influence & 0.698 & 3 \\
& Inspirational motivation & 0.715 & Connotation \\
& Intellectual stimulation & 0.854 & 3 \\
& Individualised consideration & 0.832 & 3 \\
Employee organisational & Normative commitment & 0.732 & 3 \\
commitment & Continuance commitment & 0.921 & 4 \\
& Affective commitment & 0.759 & 4 \\
& & Good & 4 \\
\hline
\end{tabular}


IM $(r=-0.728, p=0.001)$. Furthermore, correlation results showed that normative commitment and continuance commitment were significantly related to IS ( $[r=0.563 *$, $p=0.002]$ and $[r=0.232 *, p=0.000]$, respectively).

\section{Transformational leadership style and affective commitment}

Table 5 shows the multiple regression results for perceived transformational leadership style constructs and AC. The results indicate that perceived transformational leadership style significantly predicts $\mathrm{AC}(F=4.238$, sig. $=0.002$, $\left.R^{2}=0.496\right)$. The table further shows that IC and IS significantly predict $\mathrm{AC}([\beta=0.144$, sig. $=0.007]$ and $[\beta=0.129$, sig. $=$ 0.016], respectively). This is shown by the comparison of beta standardised coefficients values. The results show that IM and idealised influence do not predict $\mathrm{AC}([\beta=0.066$, sig. $=$ $0.214]$ and $[\beta=-0.055$, sig. $=0.297]$, respectively).

\section{Transformational leadership style and normative commitment}

Table 6 shows that perceived transformational leadership style significantly predicts normative commitment $(F=2.563$, sig. $\left.=0.038, R^{2}=0.009\right)$. One variable of transformational leadership style is statistically significant to the regression model: IS $(\beta=0.169$, sig. $=0.002)$.

\section{Transformational leadership style and continuance commitment}

As shown in Table 7, perceived transformational leadership style significantly predicted continuance commitment in higher education institutions $(F=5.853$, sig. $=0.000$, $\left.R^{2}=0.463\right)$ and only IS contributed to the significance of the

TABLE 3: The relationship between perceived transformational leadership style and employee organisational commitment constructs.

\begin{tabular}{lcc}
\hline Transformational leadership style & $r$ & $p$ \\
\hline Affective commitment & $0.521^{*}$ & 0.004 \\
Normative commitment & 0.165 & 0.072 \\
Continuance commitment & $0.472^{*}$ & 0.003 \\
\hline
\end{tabular}

*, Correlation is significant at the 0.01 level. regression model $(\beta=0.232$, sig. $=0.000)$. Individualised consideration, individualised influence and IM show that they do not predict continuance commitment ([ $\beta=-0.009$, sig. $=0.866],[\beta=0.074$, sig. $=0.158]$ and $[\beta=-0.066$, sig. $=0.212]$, respectively).

\section{Discussion}

The results show that perceived transformational leadership style has a positive and significant relationship with AC $(r=0.521 *, p=0.004)$. We therefore reject the null hypothesis that there is no relationship between perceived transformational leadership style and AC. Thus, the results indicate that leaders who stimulate employee morale can boost the emotional attachment to the organisation (Roueche et al., 2014). This helps the organisation in the preparation for adoption of new strategies or plan (Roueche et al., 2014). Therefore, higher education institutions in South Africa can capitalise on this by stimulating morale to prepare their staff for higher education transformation. The findings of this study are similar to the study conducted by Abdo Saeed, Gelaidan, and Ahmad (2013) in the higher educational institutions in Yemen. The study by Abdo Saeed et al. (2013) found that perceived transformational leadership style was positively related to $\mathrm{AC}(r=0.389 *)$.

The overall correlation analysis showed that there was no relationship between perceived transformational leadership style and normative commitment $(r=0.165, p=0.752)$. Therefore, we do not reject the null hypothesis that there is no significant

TABLE 5: Transformational leadership style constructs as predictors of affective commitment.

\begin{tabular}{lcccc}
\hline $\begin{array}{l}\text { Dependent variable: Affective } \\
\text { commitment }\end{array}$ & $\boldsymbol{\beta}$ & Significance & $\begin{array}{c}\text { Standard } \\
\text { error }\end{array}$ & $\boldsymbol{p}$ \\
\hline Idealised influence & 0.066 & - & 0.074 & 0.214 \\
Intellectual stimulation & 0.129 & - & 0.064 & 0.016 \\
Individualised consideration & 0.144 & - & 0.063 & 0.007 \\
Inspirational motivation & -0.055 & - & 0.039 & 0.297 \\
$R^{2}$ & - & 0.496 & - & - \\
$F$ & - & 4.238 & - & - \\
\hline$\beta$, Standardised coefficients; $R^{2}$, proportion of the variance in the dependent variable; $F$, \\
significance of the regression model.
\end{tabular}

TABLE 4: Relationship between perceived transformational leadership style constructs and employee organisational commitment facets

\begin{tabular}{|c|c|c|c|c|c|c|c|c|}
\hline Items & Measure & 1 & 2 & 3 & 4 & 5 & 6 & 7 \\
\hline \multirow[t]{2}{*}{ Idealised influence } & Pearson's correlation & 1 & - & - & - & - & - & - \\
\hline & Sig. (2-tailed) & & & & & & & \\
\hline \multirow[t]{2}{*}{ Intellectual stimulation } & Pearson's correlation & 0.116 & 1 & - & - & - & - & - \\
\hline & Sig. (2-tailed) & 0.030 & - & - & - & - & - & - \\
\hline \multirow[t]{2}{*}{ Inspirational motivation } & Pearson's correlation & 0.086 & 0.113 & 1 & - & - & - & - \\
\hline & Sig. (2-tailed) & 0.108 & 0.034 & - & - & - & - & - \\
\hline \multirow[t]{2}{*}{ Individualised consideration } & Pearson's correlation & -0.041 & 0.092 & 0.049 & 1 & - & - & - \\
\hline & Sig. (2-tailed) & 0.446 & 0.085 & 0.354 & - & - & - & - \\
\hline \multirow[t]{2}{*}{ Affective commitment } & Pearson's correlation & 0.570 & $0.844^{*}$ & -0.728 & $0.451^{*}$ & 1 & - & - \\
\hline & Sig. (2-tailed) & 0.088 & 0.007 & 0.001 & 0.005 & - & - & - \\
\hline \multirow[t]{2}{*}{ Normative commitment } & Pearson's correlation & -0.000 & $0.563 *$ & 0.018 & -0.024 & $0.453^{*}$ & 1 & - \\
\hline & Sig. (2-tailed) & 0.993 & 0.002 & 0.739 & 0.649 & 0.000 & - & - \\
\hline \multirow[t]{2}{*}{ Continuance commitment } & Pearson's correlation & 0.096 & $0.232 *$ & -0.033 & 0.006 & $0.480 *$ & $0.583 *$ & 1 \\
\hline & Sig. (2-tailed) & 0.072 & 0.000 & 0.531 & 0.907 & 0.000 & 0.000 & - \\
\hline
\end{tabular}

Source: IBM-SPSS Institute. (2013). SPSS 12.0 for windows. Chicago, IL: SPSS.

*, Correlation is significant at the 0.01 level (2-tailed).

Sig., significance. 
TABLE 6: Transformational leadership style constructs as predictors of normative commitment.

\begin{tabular}{lcccc}
\hline $\begin{array}{l}\text { Dependent variable: } \\
\text { Normative commitment }\end{array}$ & $\boldsymbol{\beta}$ & Significance & $\begin{array}{c}\text { Standard } \\
\text { error }\end{array}$ & $\boldsymbol{p}$ \\
\hline Idealised influence & -0.022 & - & 0.082 & 0.682 \\
Intellectual stimulation & 0.169 & - & 0.072 & 0.002 \\
Individualised consideration & -0.041 & - & 0.071 & 0.443 \\
Inspirational motivation & 0.003 & - & 0.043 & 0.961 \\
$R^{2}$ & - & 0.009 & - & - \\
$F$ & - & 2.563 & - & - \\
\hline
\end{tabular}

$\beta$, Standardised coefficients; $R^{2}$, proportion of the variance in the dependent variable; $F$ significance of the regression model.

TABLE 7: Transformational leadership style constructs as predictors continuance commitment.

Dependent variable:

Continuance commitment

Idealised influence

Intellectual stimulation

Individualised consideration

Inspirational motivation

$R^{2}$

$\beta$ Standardised coefficients; $R^{2}$, proportion of the variance in the dependent variable; $F$ significance of the regression model.

relationship between perceived transformational leadership style and normative commitment. The findings of this study are in contrast to the findings by Dillen (2012) who found a weak and positive relationship between perceived transformational leadership style and normative commitment in the nuclear energy cooperation. This exhibits the differences on how leadership styles in different industries influence employee organisational commitment.

The overall analysis showed that there is a moderate and significant relationship between perceived transformational leadership style and continuance commitment $(r=0.472 *$, $p=0.003)$. Therefore, we reject the null hypothesis that there is no relationship between perceived transformational leadership style and continuance commitment in higher education institutions. The results tell us that employees who have long stayed or invested a lot in the development of the organisation are more likely to stay or remain with the organisation (Ranaweera \& Menon, 2013). Thus, if employees are encouraged to be involved in higher education institutions, they are more likely to contribute more and remain with the organisation in the long run. The findings of this study agree with a study conducted in South African higher education institutions by Munyeka and Ngirande (2014) as well as another study conducted in Addis Ababa's private higher education institutions by Teshome (2012). Furthermore, the construct correlation result shows that continuance commitment is positively related to IS $(r=0.232 *$, $p=0.000)$.

\section{Transformational leadership style and affective commitment}

The results show that $49.6 \%$ of AC can be explained by perceived transformational leadership style $\left(R^{2}=0.496\right)$. Also, in the same analysis, beta standardised coefficients values show that IS is the only perceived transformational leadership style construct which predicts AC. $R^{2}$ value of 0.496 shows that a significant amount of AC can be attributed to AC. Therefore, we can conclude that leaders who continuously challenge their employees with perceptions can influence the emotional attachment of their employees.

\section{Transformational leadership style and normative commitment}

Intellectual stimulation showed that it is the only sub-scale of perceived transformational leadership style that predicts normative commitment ( $\beta=0.169, p=0.002)$. According to regression results in Table 6 , idealised influence, IC and IM predict normative commitment with no significant predictions. It should also benoted thatoverall, transformational leadership has the least predicational power to normative commitment $\left(R^{2}=0.029\right)$.

\section{Transformational leadership style and continuance commitment}

As the results show, perceived transformational leadership style has a moderate predicational power to continuance commitment $\left(R^{2}=0.463\right)$. Thus, $46.3 \%$ of continuance commitment can be explained by transformational leadership. Results further show that IS predicts continuance commitment $(\beta=0.232, p=0.000)$ unlike other sub-scales.

\section{Conclusion}

The dynamic nature of higher education recommends the need for effective leadership and committed employees to keep up with the demand put upon higher education institutions. In consideration of the various changes and reforms in higher education in several nations, it is crucial for higher education institutions to investigate the effectiveness of leadership as well as the level of commitment among employees. The plethora of literature on the transaction and perceived transformational leadership styles and employee organisational commitment addresses the issues in developed countries. Very few studies on this topic have been conducted in the developing countries, particularly in South Africa. Correlation and regression analysis were used to determine the relationship between leadership styles and employee organisational commitment in higher education institutions. The results revealed varied results in the overall analysis. Based on the study's outcomes, it is difficult to outwardly conclude that there is a relationship between perceived transformational leadership styles sub-scales and employee organisational commitment constructs. However, it is safe to say that transformation leadership style constructs are variedly related to employee organisational commitment facets. Regression analysis revealed that, to a greater extent, perceived transformational leadership style predicts employee organisational commitment. Therefore, from the results, one can conclude that each institution should conduct its own institutional diagnosis to establish which of the leadership styles or sub-scales contribute to what facet of employee organisational commitment. 


\section{Acknowledgements Competing interests}

The authors declare that they have no financial or personal relationships that may have inappropriately influenced them in writing this article.

\section{Authors' contributions}

W.N. was the main author of the article based on his master's thesis. S.T.S. was the main supervisor and H.N. was the co-supervisor of the work. S.Z. made the conceptual contribution and subject alignment.

\section{References}

Abdo Saeed, S.A., Gelaidan, H.M., \& Ahmad, F. (2013). New leadership style and lecturers' commitment in Yemen Higher Education Institutions. World Applied Sciences Journal, 21(10), 1460-1467.

Acar, Z.A. (2012). Organisational culture, leadership styles and organisational commitment in Turkish logistics industry. Procedia - Social and Behavioural Sciences, 58, 217-226. https://doi.org/10.1016/j.sbspro.2012.09.995

Allen, N.J., \& Meyer, J.P. (1990). The measurement and antecedents of affective, continuance and normative commitment to the organisation. Journal of Occupation Psychology, 63(1), 1-18. https://doi.org/10.1111/j.2044-8325.1990.tb00506.x

Ananthi, P., \& Subramaniam, B. (2011). The influence of leadership styles on organizational commitment. Master thesis. University Utara Malaysia.

Avolio, B.J. (1999). Full leadership development: Building the vital forces in organisations. Newbury, CA: Sage.

Avolio, B.J., Bass, B.M., \& Jung, D.I. (1995). MLQ Multifactor Leadership Questionnaire. Redwood, CA: Mind Garden.

Aydin, A., Sarier, Y., \& Uysal, Ş. (2013). The effect of school principals' leadership styles on teachers' organizational commitment and job satisfaction. Educational Sciences: Theory \& Practice, 13(2), 806-811.

Badat, S. (2010). The challenges of transformation in higher education and training institutions in South Africa. Development Bank of Southern Africa.

Bagraim, J., Cunnigham, P., Pieterse-Landman, E., Potgieter, T., \& Viedge, C. (2011). Organisational behaviour: A contemporary South African perspective. A. Werne (Ed.). Pretoria, SA: Van Schaik.

Balley, J.M. (2007). The role of nursing leadership in creating a mentoring culture in acute care environment. Nursing Economics, 25(3), 143-149.

Bass, B.M., \& Avolio, B.J. (1993). Transformational leadership and organisational culture. Public Administration Quaterly, 17(1), 112-117.

Benligray, S., \& Sonmez, H. (2012). Analysis of organisational commitment and workfamily conflict in view of doctors and nurses. The International Journal of Human Resource Management, 23(18), 3890-3905.

Bushra, F., Usman, A., \& Naveed, A. (2011). Effect of transformational leadership on employees' job satisfaction and organisational commitment in banking sector of Lahore (Pakistan). International Journal of Business and Social Science, 2(18), 261-267.

Clinebell, S., Skudiene, V., Trijonyte, R., \& Reardon, J. (2013). Impact of leadership styles on employee organizational commitment. Journal of Service Science, 6(1), 139-152. https://doi.org/10.19030/jss.v6i1.8244

Cloete, N., \& Maasen, P. (2015). Knowledge production and contradictory functions in African higher education. Cape Town: African Minds.

Council on Higher Education. (2013). A proposal for undergraduate curriculum reform in South Africa: The case for a flexible curriculum structure. Pretoria: CHE.

Covey, S. (2007). The transformational leadership report. Retrieved from https:// www.transformationalleadership.net

Department of Higher Education and Training. (2012). Strategic plan: Revised version for 2010/11-2014/15. Pretoria: Department of Higher Education and Training.

Dillen, R. (2012). The relationship between leadership styles and organisational commitment. Unpublished dissertation, Tshwane University of Technology, Pretoria.

Dhar, R.L. (2014). Service quality and the training of employees: The mediating role of organisational commitment. Tourism Management, 46, 419-430. https://doi. org/10.1016/j.tourman.2014.08.001

Dubinsky, A.J., Yammarino, F.J., Jolson, M.A., \& Spangler, W.D. (1995). Transformational leadership: An initial investigation in sales management. Journal of Personal Selling and Sales Management, 15(6), 17-29.

Dunn, M., Dastoor, B., \& Sims, R. (2012). Transformational leadership and organizational commitment: Across-cultural perspective. Journal of Multidisciplinary Research, $4(1), 45-60$
Fasola, O.S., Adeyemi, M.A., \& Olowe, F.T. (2013). Exploring the relationship between transformational, transactional leadership style and organizational commitment among Nigerian banks employees. International Journal of Academic Research in Economics and Management Sciences, 2(6), 96-107.

Hackman, M.Z., \& Craig, J.E. (2013). Leadership: A communication perspective. Colorado Springs, CO: Waveland Press.

Higher Education. (2015, May 30). Discussion paper prepared for the second nationa Higher Education Transformation Summit. T.l. Education, Producer. Retrieved from https://www.gov.z

Huey Yiing, L., \& Bin Ahmad, K.Z. (2009). The moderating effects of organisationa culture on the relationships between leadership behaviour and organisationa commitment and between organisational commitment and job satisfaction and performance. Leadership \& Organization Development Journal, 30(1), 53-86. https://doi.org/10.1108/01437730910927106

IBM-SPSS Institute. (2013). SPSS 12.0 for windows. Chicago, IL: SPSS.

Kent, A., \& Chelladurai, P. (2001). Perceived transformational leadership, organizational commitment, and citizenship behaviour: A case study in intercollegiate athletics. Journal of Sport Management, 15(2), 135-159. https://doi.org/10.1123/jsm. 15.2.135

Lo, M. C., Ramayah, T., Min, H.W., \& Songan, P. (2010). The relationship between leadership styles and organisational commitment in Malaysia: Role of leadermember exchange. Asia Pacific Business Review, 16(1), 79-103. https://doi. member exchange. Asia Pacific Bus

Meyer, J.P., \& Allen, N.J. (1984). Testing the 'side-bet theory' of organisational commitment: Some methodological considerations. Journal of Applied Psychology, 69(3), 372. https://doi.org/10.1037/0021-9010.69.3.372

Mignonac, K., Vandenberghe, C., Perrigot, R., El Akremi, A., \& Herrbach, O. (2015). A multi-study investigation of outcomes of franchisees' affective commitment to their franchise organization. Entrepreneurship Theory and Practice, 39(3), 461-488. https://doi.org/10.1111/etap.12050

Ministerial Oversight Committee on Transformation. (2015). The transformation of South African higher education. Pretoria, SA: Government Printer

Ministry of Education. (2002). Transformation and restructuring: A new institutiona landscape for higher education. Pretoria: Department of Higher Education and Training.

Munyeka, W., \& Ngirande, H. (2014). The impact of leadership styles on employee organisational commitment in higher learning institutions. Mediterranean Journa of Social Sciences, 5(4), 135-143.

Ndunge, W.E. (2014). Strategic leadership and change management practices at the Kenya wildlife service. Doctoral dissertation. University of Nairobi.

Nel, P., Werner, A., Du Plessis, A., Ngalo, O., Poisat, P., Sono, T., ... Botha, C. (2014). Human Resources Management (8th ed.). Cape Town, SA: Oxford University Press.

Northouse, P.G. (2010). Leadership: Theory and practice (5th ed.). Thousand Oaks, CA: Sage.

Northouse, P.G. (2015). Leadership: Theory and practice (6th ed.). London, UK: Sage.

Ozsahin, M., Zehir, C., Acar, A.Z., \& Sudak, M.K. (2013). The effects of leadership and market orientation on organisational commitment. Procedia-Social and Behavioural Sciences, 99, 363-372. https://doi.org/10.1016/j.sbspro.2013. 10.504

Pallant, J. (2010). SPSS survival manual: A step by step guide to data analysis using SPSS (4th ed.). London, UK: McGraw-H.

Ranaweera, C., \& Menon, K. (2013). For better or for worse? Adverse effects of relationship age and continuance commitment on positive and negative word of mouth. European Journal of Marketing, 47(10), 1598-1621.

Roueche, P.E., Baker III, G.A., \& Robert, R.R. (2014). Shared vision: Transformationa leadership in American community colleges. TX: Rowman \& Littlefield.

Shamir, B., Zakay, E., Breinin, E., \& Popper, M. (1998). Correlates of charismatic leader behaviour in military units: Subordinates' attitudes, unit characteristics, and superiors' appraisals of leader performance. Academy of Management Journal, 41(4), 387-409. https://doi.org/10.2307/257080

Soudien, C. (2013). Managing the planning of transformation. Unpublished paper.

Sušanj, Z., \& Jakopec, A. (2012). Fairness perceptions and job satisfaction as mediators of the relationship between leadership style and organizational commitment. Psychological Topics, 21(3), 509-526.

Teshome, T. (2012). The relationship between leadership styles and employee commitment in private higher education institutions at Addis Ababa City. (Unpublished dissertation). Addis Ababa University, Ethiopia.

Top, S., Oge, E., Atan, O., \& Gumus, S. (2015). Investigation relational levels of intensity between paternalistic and servant leadership styles and national culture, organizational commitment and subordinate responses or reactions to the leaders style. Procedia - Social and Behavioural Sciences, 181(1), 12-22. https:// doi.org/10.1016/j.sbspro.2015.04.861

Tremblay, K., Lalancette, D., \& Roseveare, D. (2012). Assessment of higher education learning outcomes feasibility study report. OECD. Retrieved from www.oecd.org

Van Knippenberg, D., \& Sitkin, S.B. (2013). A critical assessment of charismatic Transformational leadership research: Back to the drawing board? The Academy of Management Annals, 7(1), 983-1007. https://doi.org/10.1080/19416520.2013. 759433 